\title{
RANCANG BANGUN SISTEM INFORMASI GEOGRAFIS PEMETAAN UPAH MINIMUM KOTA (UMK) DAN BIAYA KEBUTUHAN HIDUP DI PROVINSI JAWA TIMUR BERBASIS WEB
}

\author{
Muhammad Rifai N. Yusuf, Yosep Agus Pranoto, F. X. Ariwibisono \\ Program Studi Teknik Informatika S1, Fakultas Teknologi Industri \\ Institut Teknologi Nasional Malang, Jalan Raya Karanglo km 2 Malang, Indonesia \\ muhammadrifainyusuf@gmail.com
}

\begin{abstract}
ABSTRAK
Pada setiap tahun pemerintah selalu menaikkan upah minimum kota maupun provinsi, ketentuan kenaikan upah minimum ini didasarkan pada UU Ketenagakerjaan No. 13 Tahun 2003, penentuan upah minimum ini bertujuan untuk memenuhi kebutuhan hidup yang layak bagi masyarakat. Masing-masing Kota/Kabupaten memiliki upah minimumnya tersendiri. Kenaikan upah minimum berdasarkan pertumbuhan ekonomi dan inflasi. Namun, pertumbuhan upah minimum ini membuat masyarakat merasa upah yang diberikan oleh pemerintah jawa timur hal ini dibuktikan dengan aksi unjuk rasa yang dilakukan oleh serikat buruh pada tanggal 20 November 2019 di depan Kantor Gubernur Jawa Timur jalan Pahlawan Surabaya. Saat ini hanya ada metode penelitian survei yang meneliti mengenai survei biaya hidup dan kenaikan Upah Minimum Kota yang dilakukan oleh BPS (Badan Pusat Statistik).

Penulis bertujuan membuat Sistem Informasi Geografis yang menampilkan UMK dan biaya kebutuhan hidup berdasarkan kategori Kota dan Kabupaten. Sehingga dengan adanya Sistem Informasi Geografis ini, pengguna dalam hal ini masyarakat dengan mudah dapat melihat data berdasarkan grafis dari peta Kabupatan dan Kota di Provinsi Jawa Timur, dalam Sistem Informasi Geografis tersebut sehingga dengan melihat data peta yang ditampilkan didalam Sistem Informasi Geografis.

Hasil pengujian Fungsional 100\% sudah berjalan sesuai dengan kebutuhan aplikasi. Hasil pengujian fungsional pada perangkat Desktop menunjukkan hasil $100 \%$ sesuai. Hasil pengujian fungsional pada perangkat mobile menunjukkan hasil $100 \%$ dibuktikan dengan tata letak tampilan yang sesuai
\end{abstract}

Kata Kunci : UMK, SBH, WebGIS, Leaflet, Jawa Timur, SIG, GeoJSON

\section{PENDAHULUAN}

Pada setiap tahun pemerintah selalu menaikkan upah minimum kota maupun provinsi, ketentuan kenaikan upah minimum ini didasarkan pada UU Ketenagakerjaan No. 13 Tahun 2003, penentuan upah minimum ini bertujuan untuk memenuhi kebutuhan hidup yang layak bagi masyarakat. Di Provinsi Jawa Timur terdapat 29 kabupaten dan 9 kota, dan Kota Surabaya sebagai ibukota provinsinya. Masingmasing Kota/Kabupaten memiliki upah minimumnya tersendiri. Kenaikan upah minimum berdasarkan pertumbuhan ekonomi dan inflasi pada provinsi terutama di Provinsi Jawa Timur. Namun, pertumbuhan upah minimum ini membuat masyarakat merasa upah yang diberikan oleh pemerintah jawa timur hal ini dibuktikan dengan aksi unjuk rasa yang dilakukan oleh serikat buruh pada tanggal 20 November 2019 di depan Kantor Gubernur Jawa Timur jalan Pahlawan Surabaya, dan tidak semua kota memiliki upah minimum yang menunjang biaya hidup hal ini disampaikan oleh serikat buruh yang mengungkapkan alasan mereka mengenai peraturan pemerintah provinsi Jawa Timur kecewa lantaran penetapan ini justru memperlebar disparitas antara kabupaten satu dengan yang lainnya.

Maka perlu dibuatkan suatu sistem informasi, yang dapat menyampaikan informasi mengenai UMK (Upah Minimum Kota) dan biaya kebutuhan hidup terutama di provinsi Jawa timur, maka penulis bertujuan membuat Sistem Informasi Geografis yang menampilkan UMK dan biaya kebutuhan hidup berdasarkan kategori Kota dan Kabupaten. Sehingga dengan adanya Sistem Informasi Geografis ini, pengguna dalam hal ini masyarakat dengan mudah dapat melihat data berdasarkan grafis dari peta Kabupatan dan Kota di Provinsi Jawa Timur.

Dengan adanya penelitian mengenai Sistem Informasi Geografis pemetaan Upah Minimum Kota (UMK) dan Biaya Kebutuhan Hidup Di Provinsi Jawa Timur diharapkan dapat memberikan jawaban kepada masyarakat terkait bagaimana menyikapi jumlah kenaikan upah minimum yang dilakukan oleh pemerintah terutama Provinsi Jawa timur dan Kabupaten/Kota didalamnya.

\section{TINJAUAN PUSTAKA}

\subsection{Penelitian Terdahulu}

Pada tahun 2018 Pranoto dkk melakukan penelitian mengenai pemetaan berbasis website untuk pusat kesehatan masyarakat di wilayah Kabupaten Malang. Penelitian tersebut memetakan pusat kesehatan yang ada di kabupaten malang dalam bentuk website[1].

Pada tahun 2019 Pradana melakukan penelitian mengalakukan penelitian mengenai Sistem Informasi Geografis Penggunaan Lahan dan Produksi Tanaman 
Pangan Kabupaten Kediri Jawa Timur, Sistem dibangun yaitu sebuah Sistem Informasi Geografis penggunaan lahan dan produksi tanaman pangan [2].

Pada tahun itu pula Budiarto melakukan penelitian Sistem Informasi Geografis Pondok Pesantren dirancang dengan menggunakan ArcGis dan Qgis serta bahasa pemrograman PHP dan HTML dimana sistem yang bermanfaat untuk masyarakat umum, khususnya Departemen Agama dalam mendapatkan informasi tentang pondok pesantren, serta fasilitas pondok pesantren yang terdapat di wilayah Kota Malang [3].

Kemudian pada tahun yang sama Arbina melakukan penelitian Sistem Infomasi Geografis Pemetaan Daerah Perkebunan Dan Komoditas Hasil Panen Provinsi Kalimantan Tengah. Penelitian ini memberikan manfaat kepada Dinas Perkebunan Kalimantan Tengah dapat mengelola data lapangan secara lebih cepat dan terperinci dengan baik dan mendukung pemerintahan daerah dalam menganalisis data-data komoditi perkebunan perlu di kembangkan suatu sistem yang memaksimalkan pemetaan tiap tanah di provinsi Kalimantan Tengah [4].

Pada Tahun 2018 Julkifli melakukan penelitian mengenai Sistem Informasi Geografis Kecamatan Woja Kabupaten Dompu Nusa Tenggara Barat. Sistem yang dirancang dengan menggunakan Artview dan Google Maps API serta bahasa pemrograman $P H P$ dan HTML penelitian ini memberikan manfaat kepada masyarakat dalam mendapatkan informasi tentang jumlah penduduk, jumlah ternak besar, pendidikan, serta fasilitas kesehatan yang terdapat di wilayah Kecamatan Woja [5].

Pada tahun itu pula Pratama melakukan penelitian serupa penelitiannya menerapkan Location Based Service yang digunakan untuk melakukan fungsi navigasi yang mengarahkan pengguna ke lokasi fasilitas kesehatan. Lokasi fasilitas ditampilkan kedalam peta dalam bentuk penanda dimana data koordinat setiap fasilitas sudah dimasukkan kemudian Informasi lengkap dari setiap fasilitas ditampilkan [6].

\subsection{Dasar Teori}

\subsubsection{Sistem Informasi Georagrafis}

Metode air terjun atau yang sering disebut metode waterfall sering dinamakan siklus hidup klasik (classic life cycle), dimana hal ini menggambarkan pendekatan yang sistematis dan juga berurutan pada pengembangan perangkat lunak, dimulai dengan spesifikasi kebutuhan pengguna lalu berlanjut melalui tahapan-tahapan perencanaan (planning), permodelan (modeling), konstruksi (construction), serta penyerahan sistem ke para pelanggan/pengguna (deployment), yang diakhiri dengan dukungan pada perangkat lunak lengkap yang dihasilkan. Dalam pengembangannya metode waterfall memiliki beberapa tahapan yang berurut diantara lain adalah: requirement (analisis kebutuhan), design system (desain sistem), coding (pengkodean), testing (pengujian) dan operation \& maintenance (pengoperasian dan perawatan) [14].

\subsubsection{Sistem Informasi Georagrafis}

Sistem Informasi Geografis merupakan data yang ditempatkan dalam konteks ruang dan waktu. Sistem Informasi Geografis (SIG) atau Geographic Information Sistem (GIS) sendiri merupakan sistem berbasis komputer yang biasanya digunakan untuk menyimpan, memanipulasi, dan menganalisa informasi geografis. SIG menggabungkan berbagai jenis data pada satu titik tertentu yang ada di bumi, menghubungkannya, menganalisanya, hingga memetakan hasilnya. Data yang diolah adalah data spasial yakni data geografis. Selain itu juga merupakan lokasi yang mempunyai koordinat tertentu [7].

Dalam SIG, ada dua jenis data yang biasa digunakan yaitu, yang pertama adalah Data Spasial yang merupakan data grafis yang menunjukkan kenampakan lokasi geografis atau tempat-tempat di muka bumi. Kemudian jenis data kedua adalah Data Atribut, data ini berfungsi untuk keberadaan berbagi objek dalam data spasial yang bersifat identitas [8].

\subsubsection{WebGIS}

WebGIS merupakan pengembangan dari aplikasi SIG berbasis web yang terintegrasi satu sama lain. WebGIS memiliki berbagai fitur yang bisa mendukung dalam menampilkan dan menganalisis data untuk bisa diakses secara bebas melalui laman internet. Dalam pengoperasiannya, WebGIS terdiri server dan client. Server berperan sebagai pusat penyedia yang saling terintegrasi melalui data, peta dan web. Kemudian pada client bertindak sebagai pengguna dalam mencari informasi yang diperlukan. WebGIS dapat menghubungkan beberapa perangkat yang menjadi satu-kesatuan (portal) untuk memudahkan para penggunanya dalam mencari informasi yang dibutuhkan. Saat ini, pengembangan WebGIS bisa digunakan dalam device android/ IOS dalam aplikasi smartphone, menggunakan desktop/laptop dengan mengakses laman website. Konten-konten yang diterima bisa diperbarui secara berkala sehingga informasi yang diterima akan selalu terbaru [9].

Fitur-fitur dalam platform WebGIS biasanya berkaitan dengan detail informasi yang akan disampaikan dan keperluan dari penggunaannya. Secara umum, beberapa fitur yang bisa dinikmati dari WebGIS diantaranya: Input Data Umum, Input Data Khusus, Unggah Koordinat dan Atribut data [9].

\subsubsection{Leaflet}

Leaflet memulai kehidupannya pada tahun 2010 sebagai "Web Maps API", JavaScript library untuk penyedia pemetaan CloudMade, tempat Agafonkin bekerja pada saat itu. Pada Mei 2011, CloudMade mengumumkan rilis pertama Leaflet, dibuat dari awal tetapi menggunakan bagian dari kode API lama [10]. 
Leaflet secara langsung dapat dibandingkan dengan OpenLayers, karena keduanya adalah open source, JavaScript library hanya sisi klien. library secara keseluruhan jauh lebih kecil, sekitar 7.000 baris kode dibandingkan dengan 230.000 OpenLayers per tahun 2015. Namun, Leaflet tidak memiliki fitur yang didukung OpenLayers, seperti Web Feature Service (WFS) dan dukungan asli untuk proyeksi selain Google Web Mercator [11].

Leaflet merupakan library javascript open source yang berguna untuk membangun aplikasi peta interaktif berbasis web. Leaflet support dengan platform mobile dan platform desktop, HTML5 dan CSS3 serta OpenLayer dan Google Maps API yang merupakan library javascript untuk membangun aplikasi peta yang sangat popular saat ini. Dengan memanfaatkan leaflet, developer yang tidak memiliki latar belakang GIS pun dapat dengan mudah menampilkan peta interaktif berbasis web pada server. Leaflet mampu menampilkan layer dari file geojson, memberi style dan membuat layer yang interaktif seperti menampilkan marker yang menampilkan popup informasi ketika di klik [12].

\subsubsection{GeoJSON}

GeoJSON adalah format standar terbuka yang dirancang untuk mewakili fitur geografis sederhana, bersama dengan atribut non-spasialnya. GeoJSON didasarkan pada JavaScript Object Notation(JSON). Fitur-fitur geometri GeoJSON meliputi: 1) Point untuk merepresentasikan alamat dan lokasi. 2) Line String untuk mereprentasikan jalan, rute dan batas. 3) Polygon untuk merepresentasikan bidang tanah. Fitur-fitur tersebut dapat dikombinasikan menjadi kumpulan multi-bagian dari fitur yang seragam yaitu MultiPoint, MultiLineString, MultiPolygon dan kumpulan multi-bagian dari fitur yang beragam yaitu GeometryCollection. Fitur GeoJSON tidak hanya mewakili entitas dari fisik bumi saja. Banyak cakupan layanan yang memanfaatkan GeoJSON seperti perutean seluler dan aplikasi navigasi. Berbeda dengan standar GIS lain, format GeoJSON ditulis dan dikelola bukan oleh organisasi standar formal, tetapi oleh kelompok kerja pengembang Internet. Hal tersebut memungkinkan pengembangan format dan implementasi GeoJSON menjadi terbuka lebar [13].

\section{METODE PENELITIAN}

\subsection{Gambaran Teknologi Yang Akan Dikembangkan}

Gambaran teknologi yang akan dikembangkan sistem ini menjelaskan proses berjalananya aplikasi seperti ditunjukkan pada Gambar 1.

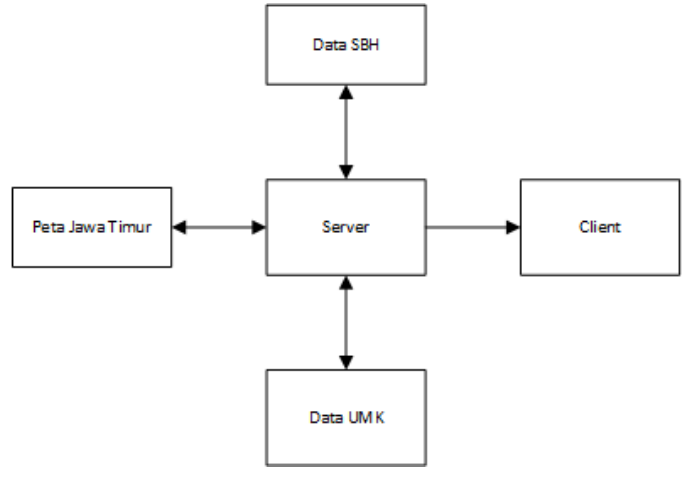

Gambar 1. Gambaran Teknologi yang akan dikembangkan

Gambar 1 merupakan gambaran teknologi yang akan dikembangkan dimana terdapat peta jawa timur beserta atribut yang diantara adalah luas wilayah, jumlah penduduk dan sektor-sektor usaha di tiap kabupaten dan kota dalam bentuk format .geojson yang akan diolah didalam WebGIS menggunakan bahasa Javascript. Terdapat data UMK (Upah Minimum Kota) dan data SBH (Survei Biaya Hidup) yang disimpan didalam database. Data ini kemudian diolah oleh webserver. untuk Bahasa yang digunakan untuk berkomunikasi antara databaseserver dan webserver adalah bahasa pemrograman PHP. Kemudian Client dalam hal ini adalah program untuk pengguna biasa dapat mengakses data tersebut menggunakan komunikasi dengan bahasa $P H P$.

\subsection{Blok Diagram Sistem}

Blok diagram adalah diagram dari sebuah sistem, dimana terdapat input, proses dan output. Pada input terdapat data spasial Kota, data atribut Kota, data UMK, dan data SBH. Pada proses terdapat analisis data spasial, analisis data atribut, analisis data UMK dan analisis data SBH, dan pada output terdapat peta Provinsi Jawa Timur, informasi kota, informasi UMK dan informasi SBH.

Proses kerja sistem informasi geografis di tunjukkan pada Gambar 2.

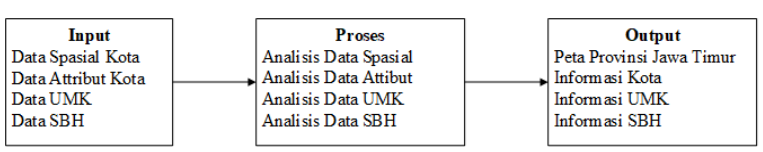

Gambar 2. Blok diagram sistem

\subsection{Flowchart Sistem}

Flowchart sistem ini menjelaskan proses berjalannya aplikasi seperti ditunjukkan pada Gambar 3. 


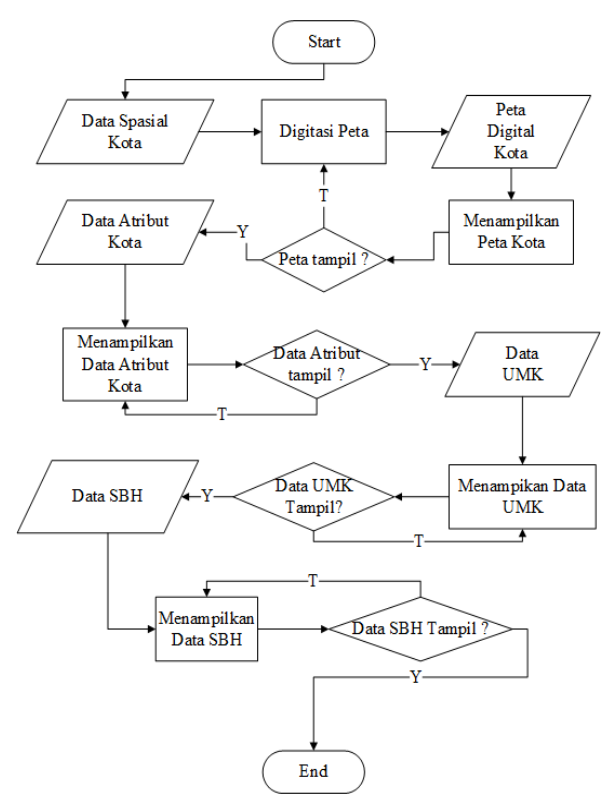

Gambar 3. Flowchart Sistem

Gambar 3. Flowchart dimulai dari meng-input data spasial kabupaten kota di provinsi Jawa Timur dan kemudian dari dari data tersebut dilakukan digitasi peta dari data spasial tadi, setelah dilakukan proses digitasi tadi maka hasilnya adalah Peta digital kabupaten/kota di Provinsi Jawa Timur. Kemudian dari peta digital tersebut dilakukan proses untuk menampilkan peta, jika tidak berhasil maka dilakukan lagi proses digitasi peta, dan jika berhasil kemudian menginput data atribut kabupaten/kota di provinsi Jawa Timur, kemudian menampilkan data tersebut, jika data tidak tampil maka ulangi proses menampilkan data, jika berhasil maka kemudian menginput data Upah Minimum Kota (UMK) kabupaten/kota di provinsi Jawa Timur beserta tahunnya, kemudian dilakukan proses menampilkan data Upah Minimum Kota (UMK), jika tidak berhasil maka diulangi proses menampilkan data Upah Minimum Kota (UMK), dan jika berhasil maka kemudian menginput data Survei Biaya Hidup (SBH), kemudian dilakukan poses menampilkan data Survei Biaya Hidup (SBH). Jika tidak berhasil maka dilakukan kembali proses menampilkan data Survei Biaya Hidup (SBH) dan jika berhasil maka program selesai.

\section{HASIL DAN PEMBAHASAN}

\subsection{Hasil}

Hasil dari program untuk tampilan pada halaman Home dapat ditunjukkan dalam Gambar 4.

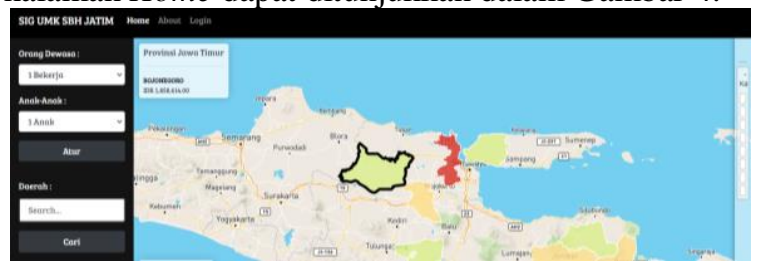

Gambar 4. Halaman Home
Hasil dari program untuk tampilan pada panel layer dapat ditunjukkan dalam Gambar 5.

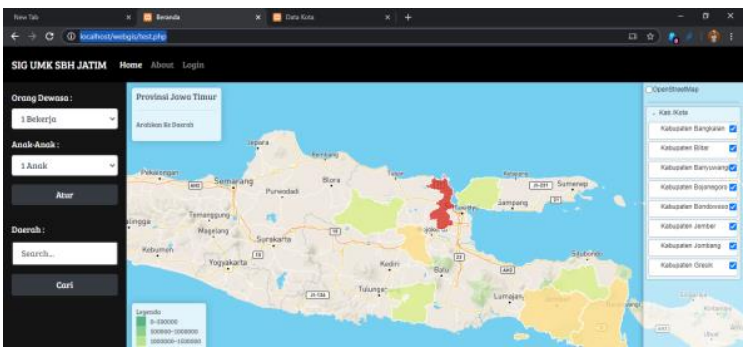

Gambar 5. Tampilan Panel Layer

Hasil dari program untuk tampilan Cari Peta dapat ditunjukkan dalam Gambar 6.

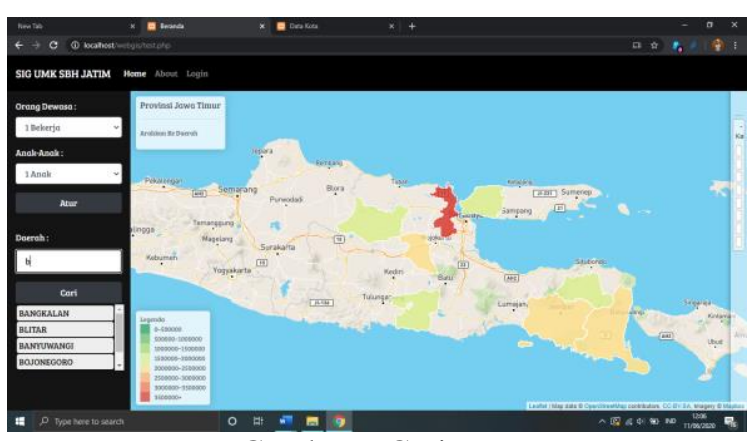

Gambar 6 Cari Peta

Hasil dari program untuk tampilan pada halaman dashboard dapat ditunjukkan dalam Gambar 7.

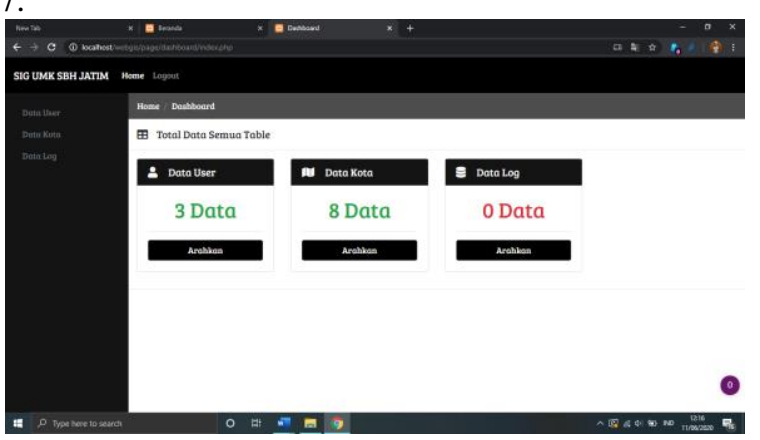

Gambar 7. Halaman Dashboard

Hasil dari program untuk tampilan data user dapat ditunjukkan dalam Gambar 8.

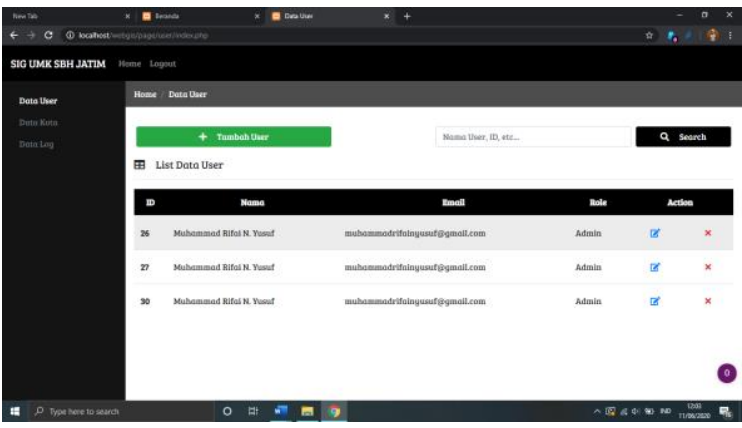

Gambar 8. Halaman Data User 
Hasil dari program untuk tampilan data kota dapat ditunjukkan dalam Gambar 9.

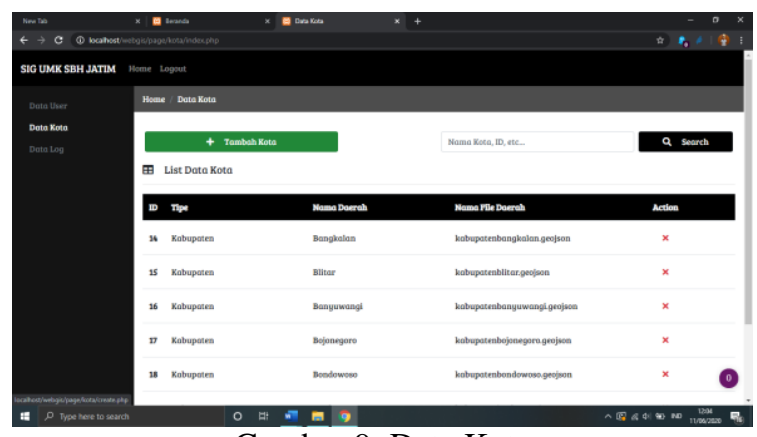

Gambar 9. Data Kota

Hasil dari program untuk tampilan tambah data kota dapat ditunjukkan dalam Gambar 10.



Gambar 10. Tambah data kota

Hasil dari program untuk tampilan pada halaman utama (depan) dapat ditunjukkan dalam Gambar 11.

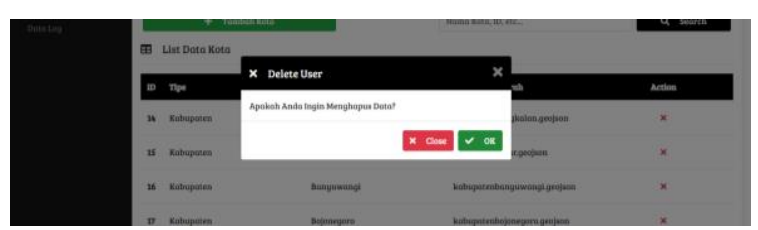

Gambar 11. Hapus Data Kota

\subsection{Pengujian fungsional}

Pengujian fungsional dilakukan untuk mengetahui apakah fungsi sudah sesuai dengan kebutuhan atau belum. Pengujian ini juga dilakukan untuk mengatasi error dan menguji validation yang seringkali dilakukan tidak sesuai dengan ketentuan penggunaan aplikasi. Tabel 1 adalah pengujian fungsi menggunakan desktop computer sebagai bahan uji.

Tabel 1 Pengujian fungsi menggunakan desktop computer

\begin{tabular}{|c|l|c|c|r|}
\hline \multirow{2}{*}{$\begin{array}{c}\text { Hak } \\
\text { Akses }\end{array}$} & \multirow{2}{*}{ Fungsional } & \multicolumn{3}{|c|}{ Browser } \\
\cline { 3 - 5 } & Home & Chrome & Edge & Opera \\
\hline \multirow{4}{*}{ User } & Cari Peta & OK & OK & OK \\
\cline { 2 - 5 } & Info Peta & OK & OK & OK \\
\cline { 2 - 5 } & Tampil Peta & OK & OK & OK \\
\hline Admin & Tambah & OK & OK & OK \\
\hline
\end{tabular}

\begin{tabular}{|l|l|c|c|c|}
\hline \multirow{7}{*}{} & User & & & \\
\cline { 2 - 5 } & Edit User & OK & OK & OK \\
\cline { 2 - 5 } Delete User & OK & OK & OK \\
\cline { 2 - 5 } & $\begin{array}{l}\text { Tampil } \\
\text { User }\end{array}$ & OK & OK & OK \\
\cline { 2 - 5 } Cari User & OK & OK & OK \\
\cline { 2 - 5 } & $\begin{array}{l}\text { Tampil } \\
\text { Kota }\end{array}$ & OK & OK & OK \\
\cline { 2 - 5 } & $\begin{array}{l}\text { Tambah } \\
\text { Kota }\end{array}$ & OK & OK & OK \\
\cline { 2 - 5 } Cari Kota & OK & OK & OK \\
\cline { 2 - 5 } & Hapus Kota & OK & OK & OK \\
\hline
\end{tabular}

Fungsional 100\% sudah berjalan sesuai dengan kebutuhan aplikasi yang dilakukan oleh browser Crome, Edge, dan Opera.

Tabel 2 Pengujian fungsi menggunakan Browser pada perangkat mobile

\begin{tabular}{|c|l|c|c|}
\hline \multirow{4}{*}{$\begin{array}{c}\text { Hak } \\
\text { Akses }\end{array}$} & Fungsional & Chrome & $\begin{array}{l}\text { Samsung } \\
\text { Internet }\end{array}$ \\
\cline { 3 - 4 } & & OK & OK \\
\hline \multirow{4}{*}{ User } & Home & OK & OK \\
\cline { 2 - 4 } & Cari Peta & OK & OK \\
\cline { 2 - 4 } & Info Peta & OK & OK \\
\cline { 2 - 4 } & Tampil Peta & OK & OK \\
\hline \multirow{5}{*}{ Admin } & Tambah User & OK & OK \\
\cline { 2 - 4 } & Edit User & OK & OK \\
\cline { 2 - 4 } & Delete User & OK & OK \\
\cline { 2 - 4 } & Tampil User & OK & OK \\
\cline { 2 - 4 } & Cari User & OK & OK \\
\cline { 2 - 4 } & Tampil Kota & OK & OK \\
\cline { 2 - 4 } & Tambah Kota & OK & OK \\
\cline { 2 - 4 } & Cari Kota & OK & OK \\
\cline { 2 - 4 } & Hapus Kota & OK &
\end{tabular}

Fungsional $100 \%$ sudah berjalan sesuai dengan kebutuhan aplikasi yang dilakukan oleh browser di perangkat mobile yaitu Chrome dan Samsung Internet yaitu aplikasi browser bawaan dari Smartphone Samsung.

\subsection{Pengujian Blackbox}

Pengujian balckbox dilakukan untuk mengetahui apakah sistem dapat berjalan sesuai dengan desain yang telah dilakukan.

Tabel 3. Pengujian blacbox

\begin{tabular}{|l|c|l|}
\hline \multicolumn{1}{|c|}{$\begin{array}{c}\text { Nama } \\
\text { Fungsi }\end{array}$} & Status & \multicolumn{1}{|c|}{ Keterangan } \\
\hline $\begin{array}{l}\text { Tampil } \\
\text { Peta }\end{array}$ & OK & $\begin{array}{l}\text { Peta dapat diload setelah ada } \\
\text { penginputan data peta dari admin, } \\
\text { membutuhkan internet untuk me- } \\
\text { load peta dari openstreetmaps. }\end{array}$ \\
\hline Cari Peta & OK & $\begin{array}{l}\text { Peta yang tersimpan dapat tampil } \\
\text { sesuai dengan key }\end{array}$ \\
\hline $\begin{array}{l}\text { Tampil } \\
\text { Peta } \\
\text { Aktif }\end{array}$ & OK & $\begin{array}{l}\text { Peta yang aktif dapat tampil } \\
\text { dengan baik, peta juga dapat } \\
\text { disembunyikan }\end{array}$ \\
\hline $\begin{array}{l}\text { Kategori } \\
\text { Peta }\end{array}$ & OK & $\begin{array}{l}\text { Peta dapat berwarna sesuai dengan } \\
\text { parameter nilai yang ditetapkan }\end{array}$ \\
\hline $\begin{array}{l}\text { Input } \\
\text { data } \text { user }\end{array}$ & OK & $\begin{array}{l}\text { Input data user dapat berjalan } \\
\text { dengan baik, terdapat validation, } \\
\text { dan alert yang dapat berjalan } \\
\text { dengan baik }\end{array}$ \\
\hline Edit data & OK & \begin{tabular}{l} 
Edit data user dapat berjalan \\
\hline
\end{tabular}
\end{tabular}




\begin{tabular}{|l|c|l|}
\hline user & & $\begin{array}{l}\text { dengan baik, dan alert yang dapat } \\
\text { berjalan dengan baik }\end{array}$ \\
\hline $\begin{array}{l}\text { Hapus } \\
\text { data } \text { sser }\end{array}$ & OK & $\begin{array}{l}\text { Hapus data user dapat berjalan } \\
\text { dengan baik, dan alert yang dapat } \\
\text { berjalan dengan baik }\end{array}$ \\
\hline $\begin{array}{l}\text { Tampil } \\
\text { data } \text { user }\end{array}$ & OK & $\begin{array}{l}\text { Tampil data user dapat berjalan } \\
\text { dengan baik, seluruh data dapat } \\
\text { tampil di dalam table yang dibuat }\end{array}$ \\
\hline $\begin{array}{l}\text { Cari data } \\
\text { user }\end{array}$ & OK & $\begin{array}{l}\text { Cara data user dapat berjalan } \\
\text { dengan baik, seluruh data yang } \\
\text { dicari dapat tampil di dalam table } \\
\text { yang dibuat }\end{array}$ \\
\hline $\begin{array}{l}\text { Tampil } \\
\text { data } \\
\text { Kota }\end{array}$ & OK & $\begin{array}{l}\text { Tampil data kota dapat berjalan } \\
\text { dengan baik, seluruh data dapat } \\
\text { tampil di dalam table yang dibuat }\end{array}$ \\
\hline $\begin{array}{l}\text { Input } \\
\text { data } \\
\text { Kota }\end{array}$ & OK & $\begin{array}{l}\text { Input data kota dapat berjalan } \\
\text { dengan baik, terdapat validation, } \\
\text { dan alert yang dapat berjalan } \\
\text { dengan baik }\end{array}$ \\
\hline $\begin{array}{l}\text { Hapus } \\
\text { data } \\
\text { Kota }\end{array}$ & OK & $\begin{array}{l}\text { Hapus data kota dapat berjalan } \\
\text { dengan baik, dan alert yang dapat } \\
\text { berjalan dengan baik }\end{array}$ \\
\hline $\begin{array}{l}\text { Cari data } \\
\text { kota }\end{array}$ & OK & $\begin{array}{l}\text { Cara data kota dapat berjalan } \\
\text { dengan baik, seluruh data yang } \\
\text { dicari dapat tampil di dalam table } \\
\text { yang dibuat }\end{array}$ \\
\hline Pada
\end{tabular}

Pada tabel 3 pengujian black box dimana seluruh fungsi dicek apakah dapat berjalan dengan baik sesuai dengan desain sistem atau sebaliknya, dari hasil pengujian yang dijalankan dapat dinyatakan bahwa sistem telah berjalan $100 \%$ sesuai dengan desain sistem.

Tabel 4 Pengujian fungsi menggunakan Browser pada perangkat mobile dengan $O S$ Berbeda

\begin{tabular}{|c|l|c|c|}
\hline \multirow{3}{*}{$\begin{array}{c}\text { Hak } \\
\text { Akses }\end{array}$} & \multirow{2}{*}{ Fungsional } & \multicolumn{2}{|c|}{ OS } \\
\cline { 3 - 4 } & & IOS 13.5 & Android 10 \\
\hline \multirow{4}{*}{ User } & Home & OK & OK \\
\cline { 2 - 4 } & Cari Peta & OK & OK \\
\cline { 2 - 4 } & Info Peta & OK & OK \\
\cline { 2 - 4 } & Tampil Peta & OK & OK \\
\hline \multirow{5}{*}{ Admin } & Tambah User & OK & OK \\
\cline { 2 - 4 } & Edit User & OK & OK \\
\cline { 2 - 4 } & Delete User & OK & OK \\
\cline { 2 - 4 } & Tampil User & OK & OK \\
\cline { 2 - 4 } & Cari User & OK & OK \\
\cline { 2 - 4 } & Tampil Kota & OK & OK \\
\cline { 2 - 4 } & Tambah Kota & OK & OK \\
\cline { 2 - 4 } & Cari Kota & OK & OK \\
\cline { 2 - 4 } & Hapus Kota & OK & OK \\
\hline
\end{tabular}

Pada tabel 4 Fungsional 100\% sudah berjalan sesuai dengan kebutuhan aplikasi yang dilakukan pada $O S$ Android 10 dan IOS 13.5. Dibuktikan dengan tataletak tampilan yang sesuai untuk mobile pada pengujian ini tidak terdapat perbedaan yang signifikan karena sistem ini berbasis web.

\section{KESIMPULAN DAN SARAN}

\subsection{Kesimpulan}

Berdasarkan beberapa pengujian yang telah dilakukan didapatkan kesimpulan :
1. Hasil pengujian blackbox dimana menguji seluruh fungsi dapat berjalan sesuai dengan desain sistem menunjukkan hasil $100 \%$.

2. Hasil pengujian fungsional menunjukkan hasil $100 \%$.

3. Hasil pengujian fungsional pada desktop menunjukkan hasil $100 \%$.

4. Hasil pengujian fungsional pada perangkat mobile menunjukkan hasil $100 \%$ dibuktikan dengan tata letak tampilan yang sesuai.

5. Hasil pengujian fungsional pada $O S$ berbeda menunjukkan hasil $100 \%$, dan tidak ada perbedaan yang signifikan.

6. Hasil pengujian pengguna dapat disimpulkan bahwa 72,7 \% menyatakan Desain dari Sistem Informasi geografis sudah baik, dan 27,3\% menyatakan cukup.

7. Hasil pengujian pengguna menyatakan handling penggunaan web dari Sistem Informasi geografis $63,6 \%$ sudah baik, $22,7 \%$ menyatakan cukup dan $13,6 \%$ menyatakan kurang.

8. Hasil pengujian pengguna menyatakan informasi dan area wilayah dapat ditampilkan dalam Sistem Informasi geografis $59,1 \%$ sudah baik dan $40,9 \%$ menyatakan cukup.

9. Hasil pengujian pengguna menyatakan pilihan yang disediakan untuk memilih pilihan orang dewasa dan anak-anak Sistem Informasi geografis $68,2 \%$ sudah baik, $22,7 \%$ menyatakan cukup dan $9,1 \%$ menyatakan kurang.

10. Hasil pengujian pengguna menyatakan aplikasi ini dapat membantu masyarakat dalam melihat jumlah UMK dan biaya hidup yang ada di Provinsi Jawa Timur dalam Sistem Informasi geografis $59,1 \%$ sudah baik, 36,4\% menyatakan cukup dan $4,5 \%$ menyatakan kurang.

\subsection{Saran}

Berdasarkan penelitian yang telah dilakukan, maka penulis dapat memberikan saran-saran untuk pengembangan selanjutnya antar lain :

1. Sistem keamanan web masih rentan membutuhkan pembuatan web dengan menggunakan object oriented programming menggunakan framework Code Igniter dengan bahasa pemrograman $P H P$.

2. Membuat web ini ke dalam bentuk mobile untuk penggunakan perangkat mobile menggunakan Android dengan bahasa pemrograman Java, ataupun Kotlin.

\section{DAFTAR PUSTAKA}

[1] Y. A. Pranoto, M. M. Rokhman and S. A. Wibowo,

"APLIKASI PEMETAAN BERBASIS WEBSITE UNTUK PUSAT KESEHATAN," Jurnal MNEMONIC, vol. I, no. 1, pp. 50-55, 2018. 
[2] A. S. P. Pradana, "SISTEM INFORMASI GEOGRAFIS PENGGUNAAN LAHAN DAN PRODUKSI TANAMAN PANGAN KABUPATEN KEDIRI JAWA TIMUR," JATI (Jurnal Mahasiswa Teknik Informatika), vol. 3, no. 2, pp. 9-15, 2019.

[3] I. F. Budiarto, "SISTEM INFORMASI GEOGRAFIS SEBARAN PONDOK PESANTREN DI KOTA MALANG," JATI (Jurnal Mahasiswa Teknik Informatika), vol. 3, no. 1, pp. 129-135, 2019.

[4] M. Arbina, "SISTEM INFOMASI GEOGRAFIS PEMETAAN DAERAH PERKEBUNAN DAN KOMODITAS HASIL PANEN PROVINSI KALIMANTAN TENGAH," JATI (Jurnal Mahasiswa Teknik Informatika), vol. 3, no. 1, pp. 165-172, 2019.

[5] Julkifli, "SISTEM INFORMASI GEOGRAFIS KECAMATAN WOJA KABUPATEN DOMPU NUSA TENGGARA BARAT," JATI (Jurnal Mahasiswa Teknik Informatika), vol. 2, no. 1, pp. 144-152, 2018.

[6] Y. A. Pratama, "SISTEM INFORMASI GEOGRAFIS FASILITAS KESEHATAN DI KOTA BATU MENGGUNAKAN METODE LOCATION BASED SERVICE ( LBS )," JATI (Jurnal Mahasiswa Teknik Informatika), vol. 2, no. 1, pp. 161-166, 2018.

[7] S. Prameswari, "Sistem Informasi Geografis : Jenis - Manfaat - Tujuan - Sumber Data," 2018. [Online]. Available: https://ilmugeografi.com/geografi-teknik/sisteminformasi-geografis. [Diakses 17 Maret 2020].

[8] Rosalia, "Kenali Jenis Data Sistem Informasi Geografi Ini Supaya Lebih Afdol!," 2017. [Online]. Available: https://www.quipper.com/id/blog/un/geografiun-sma/kenali-jenis-data-sistem-informasi- geografi-ini-supaya-lebih-afdol/. [Diakses 30 Maret 2020].

[9] geosriwijaya, "Pengertian dan Fungsi WebGeographic Information System (WebGIS)," 2018. [Online]. Available: http://geosriwijaya.com/2018/11/pengertiandan-fungsi-web-geographic-informationsystem-webgis/. [Diakses 18 Maret 2020].

[10] CloudMade, "Announcing Leaflet: a Modern Open Source JavaScript Library for Interactive Maps," 2011. [Online]. Available: http://blog.cloudmade.com/2011/05/13/announc ing-leaflet-a-modern-open-source-javascriptlibrary-for-interactive-maps/. [Diakses 30 Maret 2020].

[11] OpenHub, "Compare Projects," 2014. [Online]. Available:

https://www.openhub.net/p/compare?project_0= OpenLayers\&project_1=Leaflet. [Diakses 30 Maret 2020].

[12] S. Manurung, "MENGENAL LEAFLET JS, ALTERNATIF MEMBANGUN PETA INTERAKTIF BERBASIS WEB TANPA GOOGLE MAPS API," 2018. [Online]. Available:

https://www.sgtgeomedia.com/detailpost/menge nal-leaflet-js-alternatif-membangun-petainteraktif-berbasis-web-tanpa-google-maps-api. [Diakses 18 Maret 2020].

[13] A. Shaff, "Mengenal GeoJSON," 2020. [Online]. Available: https://goprau.com/index.php/artikel/5?judul=M engenal+GeoJSON. [Diakses 19 Maret 2020].

[14] R. S. Pressman, Rekayasa Perangkat Lunak Buku Satu, Ke-7 penyunt., Yogyakarta: Andi, 2012. 